\title{
Contribution of snow and glacier melt to discharge for highly glacierised catchments in Norway
}

\author{
M. Engelhardt ${ }^{1}$, T. V. Schuler ${ }^{1}$, and L. M. Andreassen ${ }^{2}$ \\ ${ }^{1}$ Department of Geosciences, University of Oslo, Oslo, Norway \\ ${ }^{2}$ Norwegian Water Resources and Energy Directorate, Oslo, Norway \\ Correspondence to: M. Engelhardt (markus.engelhardt@geo.uio.no)
}

Received: 27 August 2013 - Published in Hydrol. Earth Syst. Sci. Discuss.: 11 September 2013

Revised: 7 January 2014 - Accepted: 8 January 2014 - Published: 10 February 2014

\begin{abstract}
Glacierised catchments show a discharge regime that is strongly influenced by snow and glacier meltwaters. In this study, we modelled the mass balance and discharge rates for three highly glacierised catchments $(>50 \%$ glacier cover) in western Norway over the period 1961-2012. The spatial pattern of the catchments follows a gradient in climate continentality from west to east. The model input were gridded temperature and precipitation values from seNorge (http://senorge.no) which are available at daily resolution. The model accounted for accumulation of snow, transformation of snow to firn and ice, evaporation and melt. Calibration and validation were performed for each catchment based on measurements of seasonal glacier mass balances and daily discharge rates, as additional validation data served daily melt rates from sonic rangers located in the ablation zones of two of the glaciers. The discharge sources snowmelt, glacier melt and rain were analysed with respect to spatial variations and temporal evolution. Model simulations reveal an increase in the relative contribution from glacier melt to total discharge for the three catchments from less than $10 \%$ in the early 1990 s to $15-30 \%$ in the late 2000 s. The decline in precipitation by $10-20 \%$ in the same period was therefore overcompensated, resulting in an increase in annual discharge by 5-20\%. Annual discharge sums and annual glacier melt are most strongly correlated with annual and winter precipitation at the most maritime glacier and, with increased climate continentality, variations in both glacier melt contribution and annual discharge are becoming more strongly correlated with variations in summer temperatures. Therefore, glaciers in more continental climates are especially vulnerable to decrease in both annual and summer discharge with contin-
\end{abstract}

ued rise in summer temperatures and subsequent decrease in glacier extent. This may lead to significant changes to the discharge regime, with increase during spring but decline later in the year, especially for catchments in less maritime climate conditions.

\section{Introduction}

In highly glacierised catchments, meltwater constitutes a larger contribution to annual discharge than rain (Jost et al., 2012). Summer streamflow can be amplified or balanced by the presence of glaciers within the catchment (Dahlke et al., 2012), depending on the degree of glacier coverage and the interannual precipitation distribution. One sixth of the world's population is dependent on water originating from snow or glacier melt (Hock et al., 2006). In Norway, $98 \%$ of the electricity is generated by hydropower (Gebremedhin and De Oliveira Granheim, 2012) and catchments regulated for hydropower include $60 \%$ of the total glacier area (Andreassen et al., 2012). Thus, assessment of meltwater runoff is crucial for both water supply and hydropower applications. Changes in discharge are connected to variations in either air temperature or precipitation or a combination of both. Although future climatic and hydrological projections are subject to large uncertainties, ongoing climate change will result in major changes in both, timing and magnitude of the runoff regime. Glacier retreat and the release of freshwater are expected to be a key element in projections of discharge from glacierised catchments over the next decades (e.g. Huss et al., 2010; Finger et al., 2012). 


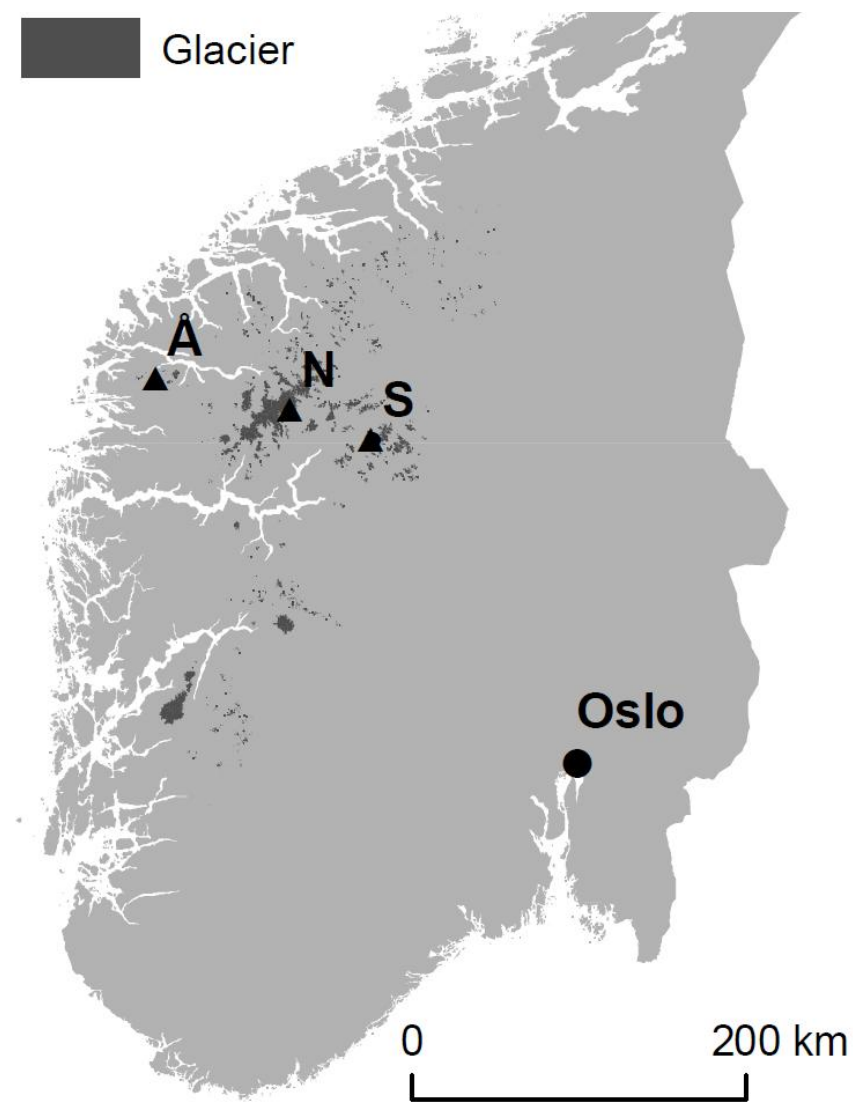

Fig. 1. Location of the study sites Ålfotbreen $(\AA)$, Nigardsbreen (N) and Storbreen $(\mathrm{S})$ within the glacierised areas in southern Norway.

The future contribution of glaciers to discharge in a changing climate is therefore subject to research in many regions of the world (e.g. Farinotti et al., 2012; Immerzeel et al., 2012; Schaner et al., 2012). Using climate model data as forcing, different studies indicate an increase in discharge in spring due to earlier onset of snowmelt, but a decline later in the year due to reduced glacier extent (e.g. Stahl et al., 2008; Huss et al., 2008). Glacial meltwater can also have relevant impacts on the hydrological regime of larger watersheds further downstream. The study of Huss (2011) revealed that for catchments with a size of $100000 \mathrm{~km}^{2}$ and $1 \%$ glacier cover in August the contribution of glaciers to discharge can be as high as $25 \%$.

Modelling melt from glaciers requires a melt model. Those models exist in a large range of different complexities (Hock et al., 2005). Since meteorological data needed for energy balance models are sparse for mountainous regions, temperature-index models have widely been used (e.g. Konz and Seibert, 2010; Jost et al., 2012; Engelhardt et al., 2013) which in the simplest form only employ air temperature and precipitation as meteorological input for snow accumulation and computing melt (see Hock, 2003, for a review). The use of a temperature-index model has been justified since surface air temperature is the most influential parameter for determining melt. Furthermore, the heat sources shortwave radiation and sensible heat flux, which are especially important for glaciers at high latitudes (Sicart et al., 2008), are closely correlated with air temperature (Ohmura, 2001).

Uncertainties in quantifying precipitation at high altitudes due to the lack of measurements represent one of the biggest problems for modelling discharge (Verbunt et al., 2003). Satellite-derived precipitation data sets can be used as a data source for modelling discharge at larger scales in regions without ground-based measurement (Li et al., 2013). Hydrological models for glacierised catchments have often been applied as grid-based models (e.g. Hock and Noetzli, 1997; Klok et al., 2001). Model performance for discharge modelling improves significantly when seasonal mass balances are used as additional calibration criteria (e.g. Finger et al., 2011; Mayr et al., 2013).

This study aims to model the contributions to discharge for three highly glacierised catchments in southern Norway along a west-east profile. For calibration we used daily discharge data and seasonal mass balance data based on interpolated point measurements (Kjøllmoen et al., 2011). The calculations were performed on a daily resolution for the period 1957-2012, including a four-year spin-up period. The model structure follows an approach suggested by Hock (2005): (1) modelling seasonal glacier mass balances and daily runoff, and (2) discharge routing of rain and meltwater taking into account the different hydraulic properties of snow, firn and ice with respect to their flow rate velocities. For parameter calibration, 10000 Monte Carlo runs were performed. We used two objective functions, the coefficient of variation for seasonal mass balances (until 2000) and the Nash-Sutcliffe coefficient for daily discharge (until 2010 for two of the catchments and 2011 for the third catchment). The parameter sets for melt and snow accumulation were validated for all catchments using seasonal mass balances for 2001-2012 and daily discharge for 2011-2012 for two of the catchments and 2012 for the third catchment. An additional validation was performed using point measurements in the ablation zones of two of the glaciers. The discharge was divided into the water sources snowmelt, glacier melt and rain. We evaluated differences in the runoff regimes between the three catchments as well as changes over time. Furthermore, we investigated correlations between discharge and the meteorological input.

\section{Study sites and input data}

The study was carried out for three catchments in southern Norway containing the glaciers Ålfotbreen, Nigardsbreen and Storbreen (Fig. 1) where both seasonal mass-balance and discharge measurements are available. The glacier coverage in each catchment is $>50 \%$ (Table 1) and at each glacier, seasonal mass balance measurements have been carried out 
Table 1. Overview of the three study catchments.

\begin{tabular}{lccc}
\hline & Àlfotbreen & Nigardsbreen & Storbreen \\
\hline Catchment size $\left(\mathrm{km}^{2}\right)$ & 8.3 & 66 & 8.0 \\
Glacier coverage $(\%)$ & 51 & 72 & 65 \\
Latitude $\left({ }^{\circ} \mathrm{N}\right)$ & 61.8 & 61.7 & 61.6 \\
Longitude $\left({ }^{\circ} \mathrm{E}\right)$ & 5.6 & 7.1 & 8.1 \\
Mean catchment elevation (m a.s.1.) & 927 & 1401 & 1597 \\
Start of mass-balance measurements & 1963 & 1962 & 1949 \\
Start of discharge measurements & 1994 & 1962 & 2010 \\
\hline
\end{tabular}

for more than $50 \mathrm{yr}$ (Andreassen et al., 2005) following the traditional stratigraphic method (Østrem and Brugman, 1991). The catchments of Alfotbreen and Storbreen are similar in size, covering about $8 \mathrm{~km}^{2}$, whereas the catchment of Nigardsbreen is about eight times as large. At all sites, discharge data are available at daily resolution, with the longest series available for Nigardsbreen $(50 \mathrm{yr})$ and the shortest at Storbreen where measurements started in September 2010.

The catchments are located at similar latitudes and therefore reflect a west-east profile from Alfotbreen close to the Norwegian west coast to Storbreen, which is located east of the main mountain divide. The climate can be characterised as very maritime at Ålfotbreen to moderate continental at Storbreen. The variations in mean annual air temperature during the model period (1961-2012) are smallest for Alfotbreen and largest for Storbreen (Fig. 2a). The summer temperatures (here: May-September) show a similar progression for all catchments (Fig. 2c), with increasing values from 1961 to 1970 and from 1995 to 2005 and constant to slightly decreasing values from 1970 to 1995 and from 2005 to 2012. The difference in summer temperature between the sites mainly reflects the mean catchment elevation which increases from west (̊lfotbreen) towards east (Storbreen). From the early 1990s to the 2000s all three sites experienced an increase in mean summer temperature of about $1-1.5 \mathrm{~K}$.

Precipitation decreases considerably from west to east. The mean annual precipitation sum ranges from more than $5000 \mathrm{~mm}$ for Alfotbreen to less than $2000 \mathrm{~mm}$ for Storbreen (Fig. 2b). In contrast to temperature, the annual precipitation sums show least variations at Storbreen where they remained almost constant between the 1960s and 1990s. Afterwards annual precipitation decreased slightly by about $10 \%$ in the 2000s. Both Ålfotbreen and Nigardsbreen show similar variations in precipitation; however, they are more pronounced at Alfotbreen: an increase in annual precipitation of $50 \%$ (20\%) from the 1960s to the end of the 1980s at Alfotbreen (Nigardsbreen) is followed by a decline of $20 \%$ (10\%) towards the end of the 2000s (Fig. 2b). Winter precipitation (here: October-April), which predominantly falls as snow, follows a similar pattern for all catchments compared to the annual precipitation. On average, winter precipitation yields about two thirds of the annual sums (Fig. 2d).
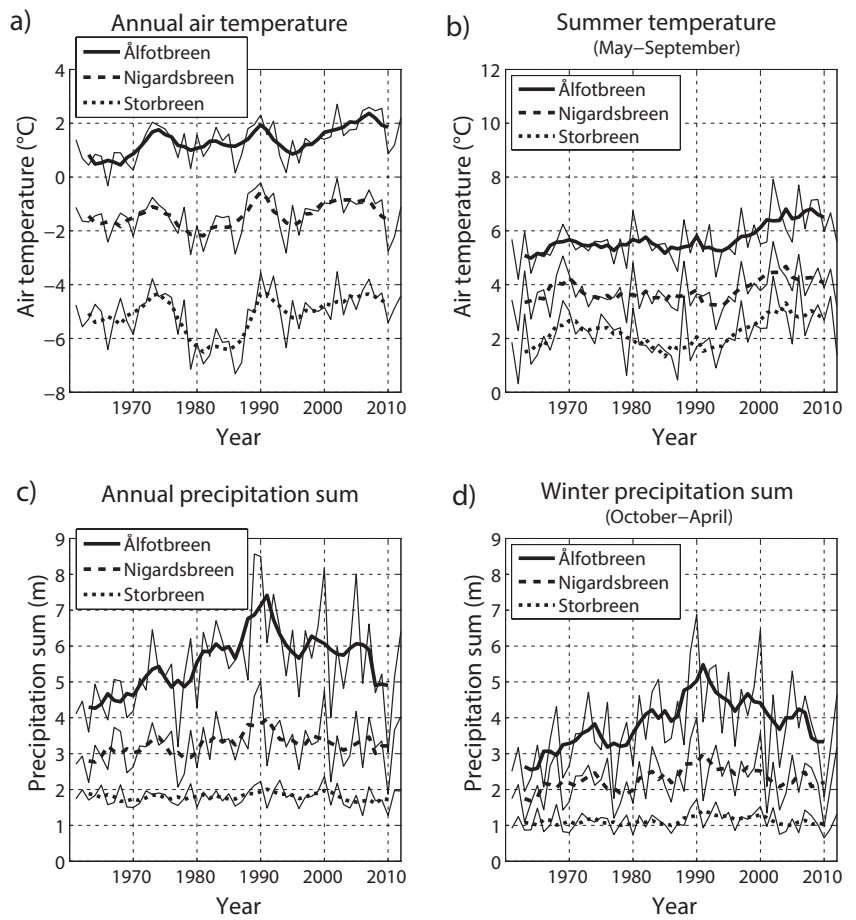

Fig. 2. Air temperature and precipitation data with $5 \mathrm{yr}$ moving averages for the three catchments based on seNorge data.

For the study we used the gridded temperature and precipitation from seNorge (www.senorge.no). The data are based on station measurements which are interpolated on a $1 \mathrm{~km}$ horizontal grid for all of mainland Norway on a daily basis from 1957 to the present (Mohr, 2008). Despite some weaknesses with the inter- and extrapolation of precipitation in mountainous regions, different evaluation studies (Mohr, 2009; Dyrrdal, 2010; Engelhardt et al., 2012; Saloranta, 2012) found the gridded data of seNorge to be suitable for mass-balance modelling especially due to its high spatial resolution. 


\section{Methods}

\subsection{Precipitation correction}

To account for uncertainties in the precipitation data from seNorge associated especially with the vertical adjustment, we applied a constant precipitation correction factor for each catchment to fulfil the (accumulated) water balance over the hydrological years (1 October-30 September) of available discharge data.

Neglecting in- or outflow of groundwater, the water balance equation reads (all terms in $\mathrm{m} \mathrm{a}^{-1}$ ):

$P=Q+V+\Delta S$,

where $P$ denotes precipitation, $Q$ discharge and $V$ evaporation. $\Delta S$ is a storage term accounting for all water that remains in or additionally leaves the domain.

Snow- or glacier melt within the domain is therefore a negative contribution to the storage term. Considering highly glacierised catchments, we assumed the storage term to be the accumulated glacier mass balance over the period of measurements. Outside the glacierised areas, no storage was assumed. For evaporation we used the gridded data provided from seNorge which were only calculated for the nonglacierised areas and set to zero for the glacierised areas (Sælthun, 1996). This is justified since evaporation and condensation on glaciers may balance each other and their net effect is not likely to influence discharge in a significant way (e.g. Braun et al., 1994). Since the gridded precipitation data from seNorge for the glacier parts of all catchments $\left(P_{\mathrm{g}}\right)$ had already been evaluated in the study by Engelhardt et al. (2012), we now used the calculated precipitation correction factors $\left(F_{\mathrm{g}}\right)$ from that study for the glacierised areas and calculated the correction factors for the precipitation $\left(P_{\mathrm{ng}}\right)$ of the non-glacierised parts $\left(F_{\mathrm{ng}}\right)$ of the catchments. The water balance equation for the glacierised and non-glacierised areas was then modified to

$$
Q=\underbrace{\frac{P_{\mathrm{g}}}{F_{\mathrm{g}}}-\Delta S}_{\text {glacier area }}+\underbrace{\frac{P_{\mathrm{ng}}}{F_{\mathrm{ng}}}-V}_{\text {non-glacier area }} .
$$

Using the measurements of accumulated mass balance (e.g. Kjøllmoen et al., 2011) and discharge, the water balance was calculated over the period of available discharge data, which is 50 (hydrological) years for Nigardsbreen, $18 \mathrm{yr}$ for Ålfotbreen and two years for Storbreen. The correction factors $F_{\text {ng }}$ of the seNorge precipitation were calculated as an average over the respective periods (Table 2).

With the gained correction factors, the precipitation input for the model $\left(P_{\text {input }}\right)$ is dependent on the grid point location (representing glacierised or non-glacierised areas) and was calculated to

$P_{\text {input }}=\frac{P_{\text {seNorge }}}{F_{\mathrm{n} / \mathrm{ng}}}$.

\subsection{Model set-up}

The study was performed with a conceptual model based on a temperature index approach including potential solar radiation. The glacier mass balances and meltwater runoff were calculated using air temperature and the corrected precipitation from seNorge (Sect. 3.1) as input. The model runs independently for each grid cell at a daily resolution. Despite the $1 \mathrm{~km}$ grid resolution, the model accounts for smaller areas along the glacier and catchment margins by weighting each grid cell with its contribution to the catchment and glacier ratio. The calculations covered the hydrological years 19612012 (1 October 1960-30 September 2012) and a preceding spin-up period (1957-1960) to accumulate snow and firn. The model accounts for mass gain due to accumulation of snow and mass loss due to evaporation and melting of snow and ice. The transition from snow to rain occurs within an interval of $2 \mathrm{~K}$ where the precipitation linearly shifts from snow to rain. The centre of this interval is denoted as the threshold temperature for snow $\left(T_{\mathrm{s}}\right)$.

To account for the transition of snow to firn and ice, snow that has not melted away during summer was defined as becoming firn at the beginning of each hydrological year (1 October). Additionally, $25 \%$ of the existing firn was assumed to become ice, leading to an average transition time from firn to ice of $4 \mathrm{yr}$, which is in accordance with a simple time function introduced by Martinec (1977). The conceptual model calculates daily melt of snow, firn or ice $M_{\text {snow/ice }}$ by using a distributed temperature-index approach including potential solar radiation as used e.g. in Hock (1999) or Engelhardt et al. (2013). Melt is calculated if the seNorge temperature $T_{\mathrm{sn}}>T_{\mathrm{m}}$ (threshold temperature for melt):

$M_{\text {snow/firn/ice }}=\left(\Theta+R_{\text {snow } / \text { firn/ice }} \cdot I\right) \cdot\left(T_{\mathrm{sn}}-T_{\mathrm{m}}\right)$,

with the melt factor $\Theta$, the respective radiation coefficients for snow, firn and ice $R_{\text {snow/firn/ice }}$ and the potential direct solar radiation $I$. The potential solar radiation is dependent on latitude and day of year, and its usage effectuates a sinusoidal variation in the melt factor in the course of a year. Modifications due to exposition or shading effects of surrounding slopes were not accounted for as the model grid resolution would not appropriately resolve these phenomena. However, using potential radiation can significantly increase model performance (Huss et al., 2009). Since the melt efficiency of firn is higher than for snow but lower than for ice, the radiation factors for firn $\left(R_{\mathrm{firn}}\right)$ were assumed to be the mean of the ones for snow $\left(R_{\text {snow }}\right)$ and ice $\left(R_{\text {ice }}\right)$. At each grid point, firn starts to melt when the snow has melted and ice starts to melt once the firn has melted away.

The model calculates the reference surface mass balance (Elsberg et al., 2001). The area on which the calculations are based is the same area for which the available glacier massbalance measurements have been performed (e.g. Kjøllmoen et al., 2011). This glacier area was e.g. $47.8 \mathrm{~km}^{2}$ from $1984-$ 2008 for Nigardsbreen and was updated to $47.2 \mathrm{~km}^{2}$ in 2009 . 
Table 2. Water balance components (in $\mathrm{m} \mathrm{a}^{-1}$ ) and precipitation correction factors $(F)$ for the glacierised (g) and non-glacierised (ng) parts of the three catchments. All water balance components are specific quantities for the respective catchment area (Table 1).

\begin{tabular}{lccc}
\hline & Alfotbreen & Nigardsbreen & Storbreen \\
\hline Period (hydrological years) & $1995-2012$ & $1963-2012$ & $2011-2012$ \\
Precipitation $(g)$ & 3.37 & 2.67 & 1.06 \\
Precipitation $(n g)$ & 2.43 & 0.62 & 0.64 \\
Discharge & 5.66 & 3.01 & 2.60 \\
Evaporation & 0.06 & 0.05 & 0.02 \\
Accumulated mass balance & -0.24 & 0.25 & -0.65 \\
$F_{\mathrm{g}}$ (from Engelhardt et al., 2012$)$ & 1.01 & 1.00 & 0.80 \\
$F_{\text {ng }}$ & 1.13 & 0.99 & 1.00 \\
\hline
\end{tabular}

All changes in glacier area during the model period are not larger than $6 \%$ of the respective glacier area. To account even for such small area changes in the model, the glacier melt contribution of the grid point representing the lowest glacier altitude is changed by adjusting the glacier ratio of this grid point.

Besides melting, the model also accounts for a delay in runoff by using a linear reservoir for daily discharge for each catchment. The water from melt and rain is distributed over time using three storage constants for the linear reservoirs depending on the surface property snow, firn or ice.

At a daily time step $(t)$ the reservoirs $(W)$ for each grid point $(i)$ were updated based on the previous values $W_{i}(t-1)$ and the calculated meltwater and rain for this location:

$W_{i}(t)=W_{i}(t-1)+M_{i}(t)+R_{i}(t)$,

where $M$ denotes the calculated melt rates and $R$ the rain (precipitation at $T>\mathrm{T}_{s}$ ).

The discharge for each grid $q_{i}$ was calculated individually using a storage constant $\left(c_{\text {snow/firn/ice }}\right)$ dependent on the surface property of this grid point:

$q_{i}(t)=c_{\text {snow/firn/ice }} \cdot W_{i}(t)$.

The daily model resolution allowed the usage of a constant rather than a time-varying storage coefficient as used e.g. in Stahl et al. (2008). No water storage was applied for grid cells which are not covered by snow, firn or ice, since a fast runoff is assumed for these areas located in mountainous terrain and close to the discharge station. Thus, rain was treated like meltwater when falling on snow, firn, or ice, but was counted as discharge for the same day falling on areas free of snow or ice.

After the daily discharge rate was calculated, the water reservoir was updated and the daily simulated discharge for the whole catchment $\left(Q_{\mathrm{m}}\right)$ was calculated as the sum from all grid points:

$$
\begin{aligned}
& W_{i}(t)=W_{i}(t)-q_{i}(t) \\
& Q_{\mathrm{m}}(t)=\sum_{i} q_{i}(t)
\end{aligned}
$$

\subsection{Calibration of model parameters and validation of model performance}

For the calibration scheme we used for each catchment a Monte Carlo run of 10000 random parameter sets consisting of eight parameters given in Table 3. For each parameter set, two optimization criteria were calculated: (1) the coefficient of variation $\left(c_{\mathrm{V}}\right)$ between measured (meas) and modelled (mod) glacier-wide seasonal mass balances $(b)$ for the period 1961-2000, and (2) the Nash-Sutcliffe coefficient (E) for daily discharge for the period 1995-2010 at Ålfotbreen, 1963-2010 at Nigardsbreen, and for the year 2011 at Storbreen:

$c_{\mathrm{v}}=\frac{\sigma}{\left|b_{\text {meas }}\right|}$ with

$\sigma=\sqrt{\frac{\left(b_{\text {mod }}-b_{\text {meas }}\right)^{2}}{n}}$ and

$E=1-\frac{\sum\left(Q_{0}-Q_{\mathrm{m}}\right)^{2}}{\sum\left(Q_{0}-\overline{Q_{0}}\right)^{2}}$,

where $n$ denotes the number of measured $b$ and $\mathrm{Q}_{0}$ measured daily discharge sums.

Following an approach by Konz and Seibert (2010), the combination of the two optimization criteria was performed by ranking the parameter sets separately according to their mass balance and runoff qualities. The ranks were summed and the 100 parameter sets with the lowest rank sums were selected. The ensemble average of the selected parameter values is given in Table 3 .

For each catchment, the model was run for each of the 100 best parameter sets over the period of available seNorge data (1957-2012). The model runs were validated for all catchments with the seasonal mass balances for 2001-2012 and with daily discharge for 2011-2012 for Alfotbreen and Nigardsbreen and 2012 for Storbreen.

As additional validation of the model performance, we used weekly melt rates measured with sonic rangers in the ablation zones of Storbreen (Andreassen et al., 2008) and 
Table 3. Median of the 100 best parameter sets and model performance (coefficients of variation for seasonal mass balances and the NashSutcliffe coefficient for daily discharge sums) of the 100 best ensemble runs for the calibration periods.

\begin{tabular}{llcccl}
\hline Parameter & Description & Ålfotbreen & Nigardsbreen & Storbreen & Unit \\
\hline$T_{0}$ & melt threshold factor & 0.2 & -0.2 & -0.3 & ${ }^{\circ} \mathrm{C}$ \\
$T_{\mathrm{S}}$ & snow threshold factor & 2.5 & 1.3 & 1.4 & ${ }^{\circ} \mathrm{C}$ \\
$R_{\text {Snow }}$ & radiation coefficient for snow & 4.3 & 3.8 & 3.6 & $\mathrm{~mm} \mathrm{~K}^{-1} \mathrm{~d}^{-1} \mathrm{~kW}^{-1} \mathrm{~m}^{2}$ \\
$R_{\text {ice }}$ & radiation coefficient for ice & 7.1 & 7.0 & 5.6 & $\mathrm{~mm} \mathrm{~K}^{-1} \mathrm{~d}^{-1} \mathrm{~kW}^{-1} \mathrm{~m}^{2}$ \\
$\Theta$ & melt factor & 3.9 & 2.9 & 2.6 & $\mathrm{~mm} \mathrm{~K}^{-1} \mathrm{~d}^{-1}$ \\
$c_{\text {snow }}$ & storage constant for snow & 0.28 & 0.19 & 0.54 & $\mathrm{~d}^{-1}$ \\
$c_{\text {firn }}$ & storage constant for firn & 0.40 & 0.66 & 0.68 & $\mathrm{~d}^{-1}$ \\
$c_{\text {ice }}$ & storage constant for ice & 0.64 & 0.72 & 0.83 & $\mathrm{~d}^{-1}$ \\
$c_{\mathrm{V}}$ & coefficient of variation & $0.18-0.20$ & $0.16-0.17$ & $0.15-0.16$ & - \\
$E$ & Nash-Sutcliffe coefficient & $0.76-0.78$ & $0.85-0.88$ & $0.88-0.91$ & - \\
\hline
\end{tabular}

Nigardsbreen. Data were available for 84 weeks with melt during the period 2002-2012 for Storbreen and for 43 weeks from the 2011 and 2012 melt seasons for Nigardsbreen. Weeks with data gaps or snow fall events were excluded. The melt rates at these two point locations were calculated by using the ensemble mean of the calibrated parameter set. The temperature and precipitation input for the sonic ranger locations were retrieved by interpolating the daily seNorge temperature and precipitation data to the horizontal sonic ranger positions and adjusting the data to the altitude, using the vertical gradients from the seNorge routines.

\section{Results}

The model performance for seasonal mass balance and daily discharge expressed by the coefficient of variation and the Nash-Sutcliffe coefficient was increasing from Ålfotbreen, the most maritime study site, towards Storbreen (Table 3). While there was little difference in modelling seasonal mass balances with coefficient of variation values between 0.15 and 0.20 , daily discharge was modelled better for both $\mathrm{Ni}$ gardsbreen and Storbreen, with a Nash-Sutcliffe coefficient $E$ between 0.85 and 0.91 than at Ålfotbreen $(E=0.76-0.78)$.

The parameter uncertainty of the different individual model parameters in the 100 best model runs is given in Fig. 3. There was little difference in the uncertainty of the melt threshold temperature between the catchments. The snow threshold temperature showed largest uncertainty at Ålfotbreen, where this parameter showed the largest median value of $2.5^{\circ} \mathrm{C}$. For the melt parameters, the uncertainty in the two radiation coefficients was larger than for the melt factor. The storage coefficients increased from snow to ice, yielding faster runoff for meltwater from ice melt than from snowmelt.

The seasonal mass balances for the validation period 2001-2012 were better modelled for the Nigardsbreen and Storbreen glaciers, where absolute values of mass balances
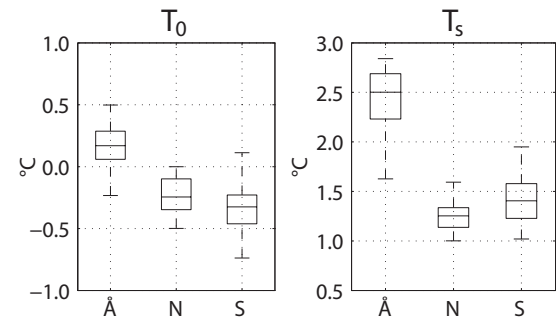

Å: Ålfotbreen

$\mathrm{N}$ : Nigardsbreen

S: Storbreen
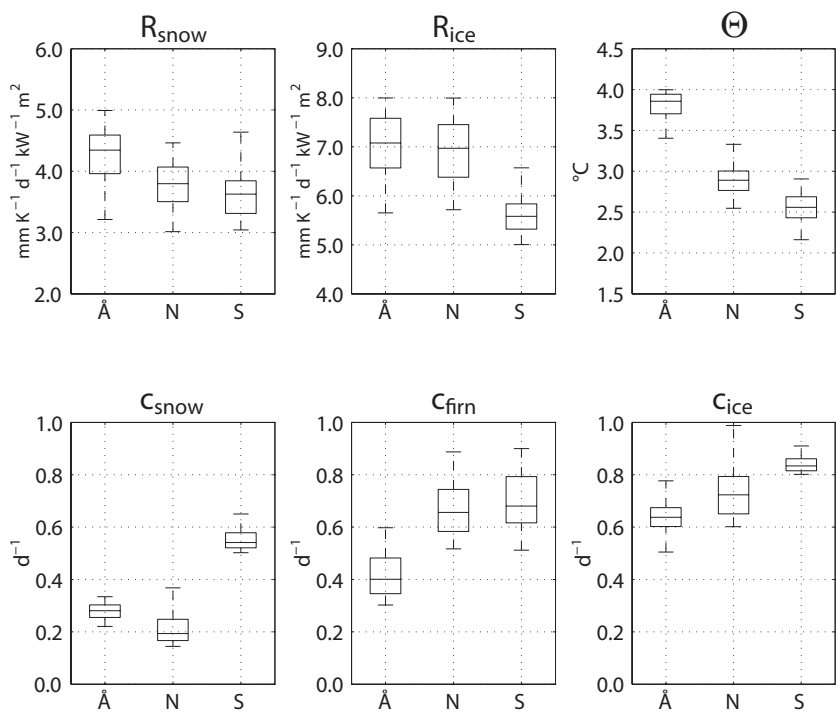

Fig. 3. Parameter uncertainty of the 100 best runs. In each box, the central mark is the median, the edges of the box are the 25th and 75th percentiles, and the whiskers extend to the most extreme data points. The ordinates indicate the parameter range in the calibration scheme. Parameter description and median values are given in Table 3. 

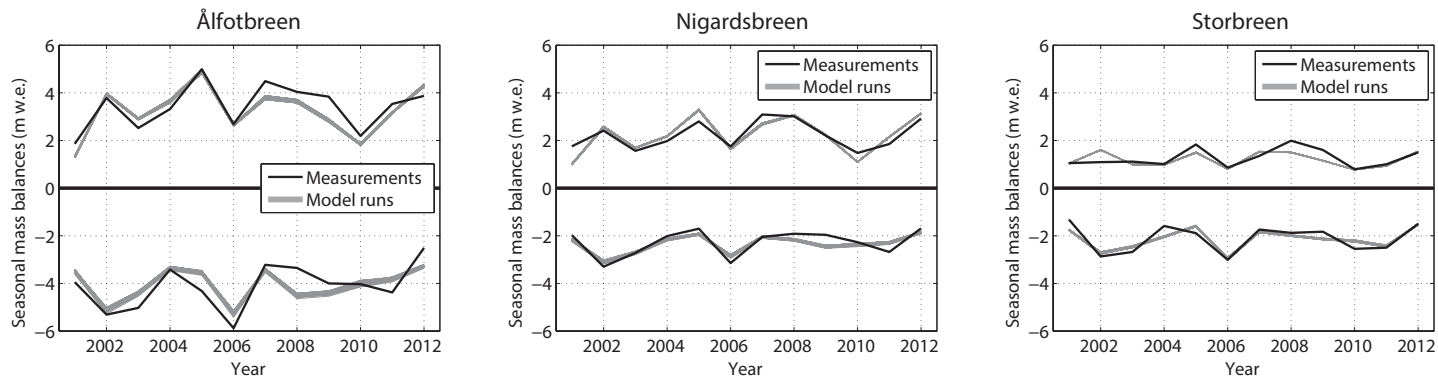

Fig. 4. Model performance for seasonal glacier mass balances for the three catchments for the validation period 2001-2012.
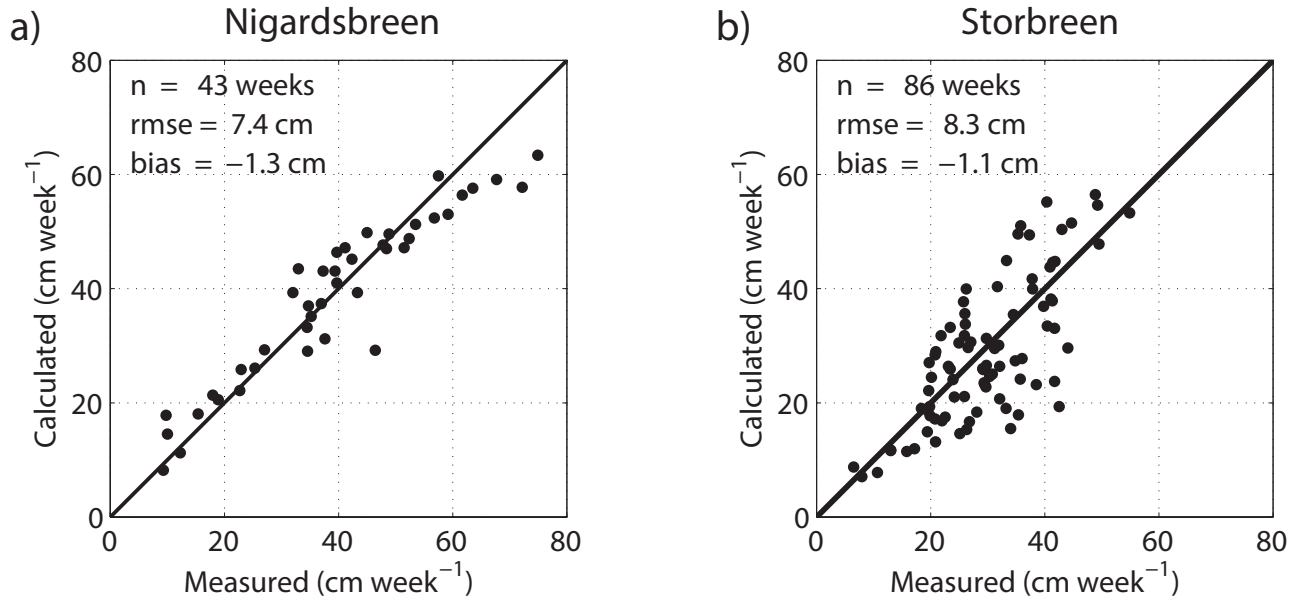

Fig. 5. Model performance for weekly melt at the sonic ranger position of Nigardsbreen (2011-2012) and Storbreen (2002-2012). Data for the modellings represent the mean of the 100 best model runs.

were smaller and year-to-year variations lower than at Ålfotbreen (Fig. 4).

The validation of the model parameter for calculating weekly melt at the sonic ranger positions showed a larger spread at Storbreen than at Nigardsbreen (Fig. 5). However, for Nigardsbreen the model had a tendency to underestimate high discharge values. At both locations the bias between modelled and measured melt rates was low, which means that the accumulated melt was modelled close to the measurements.

Daily discharge was simulated well at all catchments (Fig. 6). Although daily peak flows can be as high as $70 \mathrm{~mm} \mathrm{~d}^{-1}$ at all catchments, variations in daily discharge were largest at Ålfotbreen and smallest at Nigardsbreen. Nigardsbreen and Storbreen showed a similar discharge pattern in the course of the year.

The annual sums of the modelled specific discharge over the period 1961-2012 revealed an overall increase for all three evaluated catchments for this period of about $20 \%$ (Fig. 7), but also periods of declining discharge. At Ålfotbreen the discharge increased by about $40 \%$ between the 1960s and the late 1980s followed by large variability within the following two decades, with annual discharge sums rang- ing from 4 to $8 \mathrm{~m} \mathrm{a}^{-1}$. At Nigardsbreen and Storbreen, the annual discharge showed much smaller changes within the model period. Nevertheless, the 2000s were the decade when discharge was highest for these two catchments and about $20 \%$ above average. The measured annual discharge sums corresponded quite well to the model simulations. However, the available data series for Storbreen were quite short, with only $2 \mathrm{yr}$ of measurements.

Larger variations than for the discharge sums were visible in the proportion of the contributing discharge sources (Fig. 8). For all catchments the largest contribution denoted from snowmelt, which accounted for roughly $60 \%$ of the annual discharge. Until the 1990s, Storbreen showed the highest relative contribution from snowmelt among the study sites, with values up to $70 \%$ in the $5 \mathrm{yr}$ moving averages in the 1960s and early 1990s. Most remarkable was the decrease from the 1990s to the 2000s, when the snowmelt contribution to discharge decreased at all sites from $65-70 \%$ to $50-60 \%$. This decrease was larger for the small Ålfotbreen and Storbreen glaciers, whereas at Nigardsbreen the contribution of snowmelt to discharge during the model period was the most constant of all the catchments. Among our study sites, the relative contribution from glacier melt became larger with 
a) Ålfotbreen

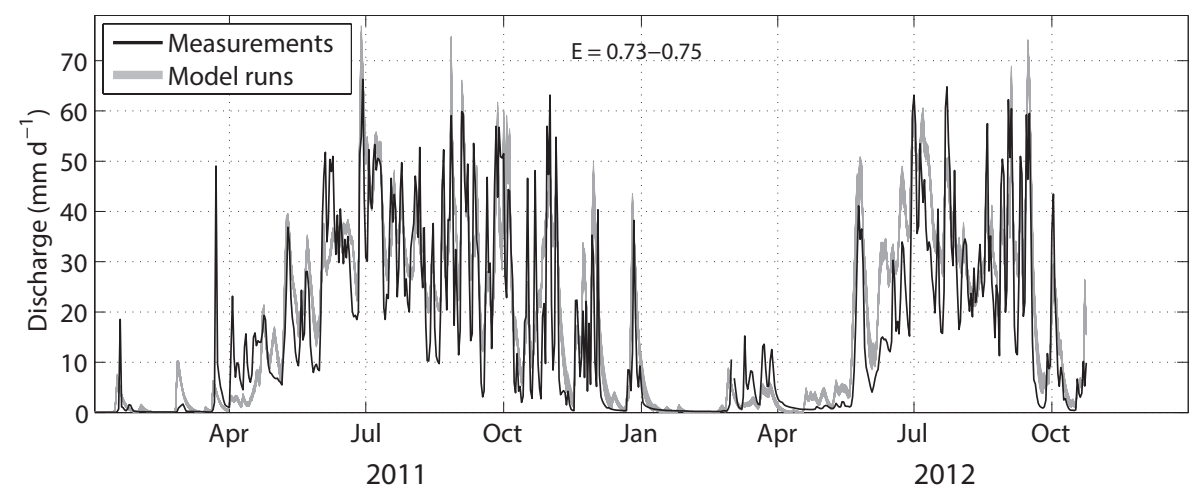

b)

Nigardsbreen

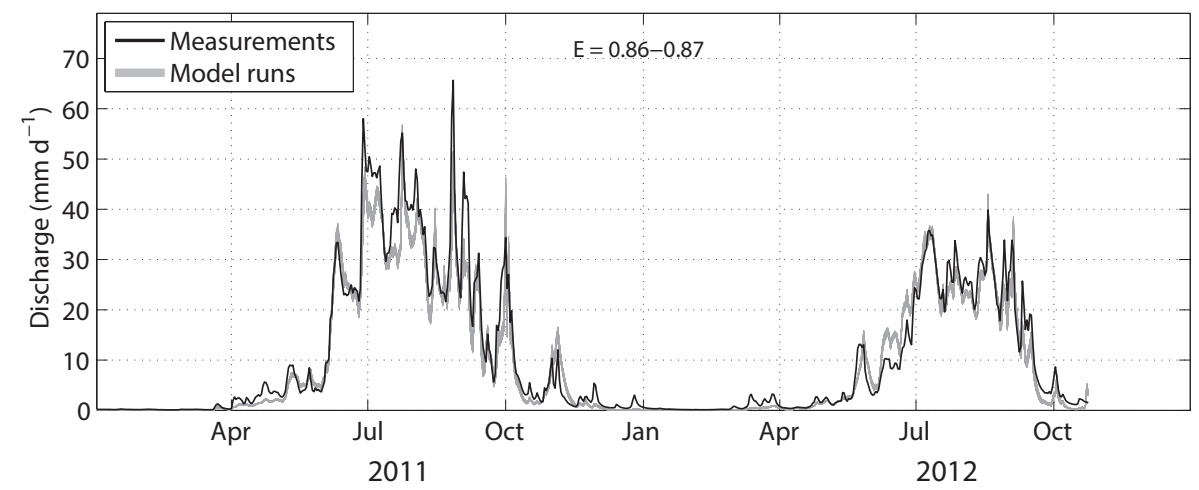

c)

Storbreen

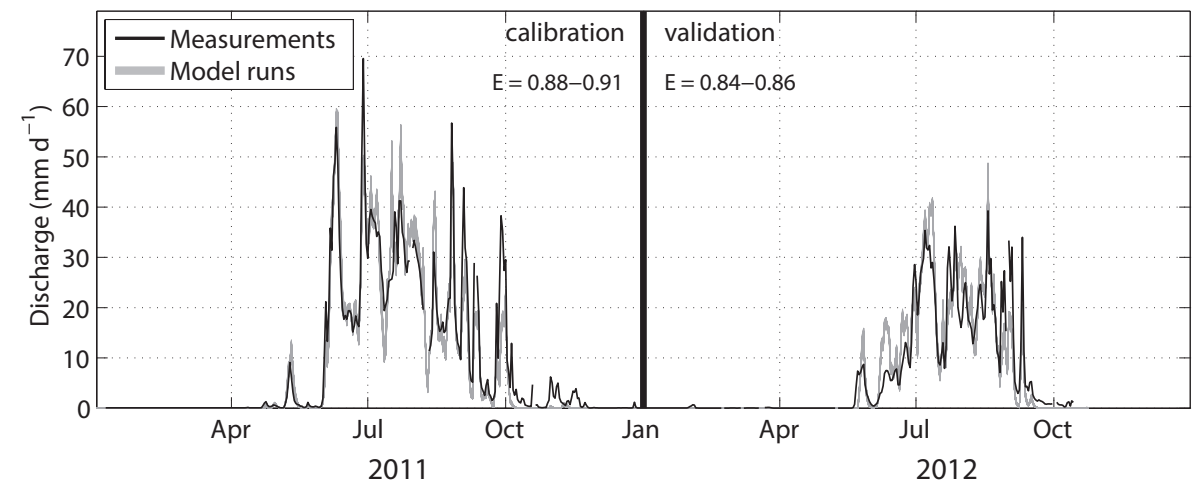

Fig. 6. Model performance for daily discharge sums at the three catchments for the validation years 2011 and 2012. Note: at Storbreen, daily discharge for 2011 is used for calibration, and 2012 for validation.

increasing climate continentality from west (Ålfotbreen) to east (Storbreen). A decrease from the 1970s to a minimum in the early 1990s, when at all sites less than $10 \%$ of the annual discharge originated in glacier melt, was followed by an increase in the 2000s, surpassing the high values from the 1960s and 1970s. At Storbreen the relative contribution from glacier melt accounted for more than $25 \%$ of the annual discharge in the first decade of the 21 st century.

The remaining water source for discharge is rain. Its relative contribution was highest for Ålfotbreen $(\sim 37 \%)$, moderate for Nigardsbreen $(\sim 27 \%)$ and lowest for Storbreen $(\sim 19 \%)$. While changes over time were smallest at Storbreen, for Ålfotbreen and to a lesser extent also for Nigardsbreen the relative component of rain to discharge had a maximum in the 1980s and a minimum in the 1960s and 1990s.

The uncertainty of the contributing discharge sources among the 100 best ranked parameter sets was highest for snowmelt, spreading in a band of $5 \%$, and lowest for glacier melt. For all discharge sources, the uncertainty was slightly higher for Ålfotbreen than for the other catchments.

The evaluation of the monthly discharge for the periods 1991-2000 and 2001-2010 revealed that for all three 


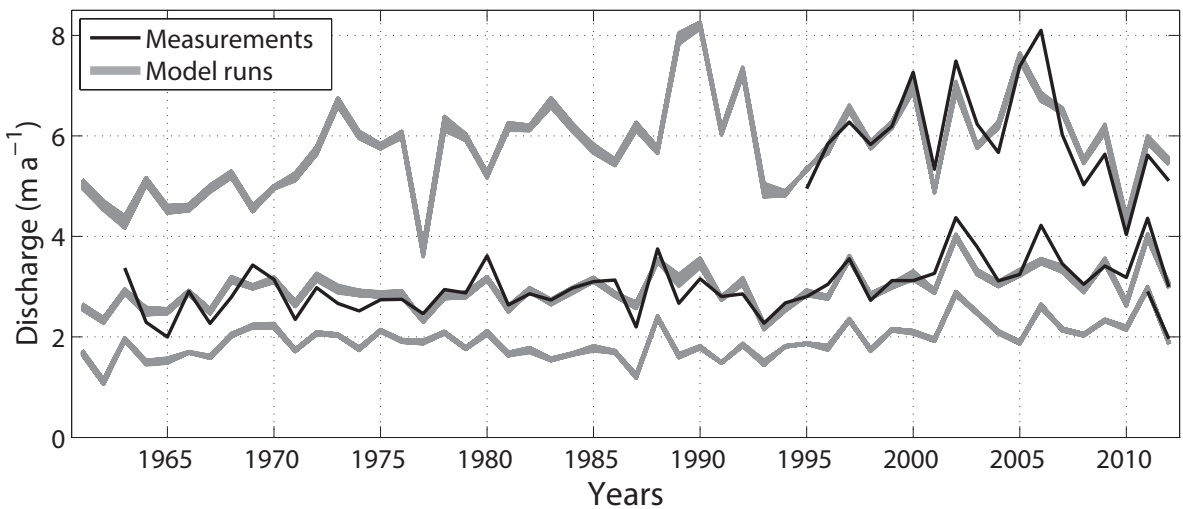

Fig. 7. Mean annual discharge sums for the catchments of Ålfotbreen (upper lines), Nigardsbreen (centre lines) and Storbreen (lower lines) for the period 1961-2012.
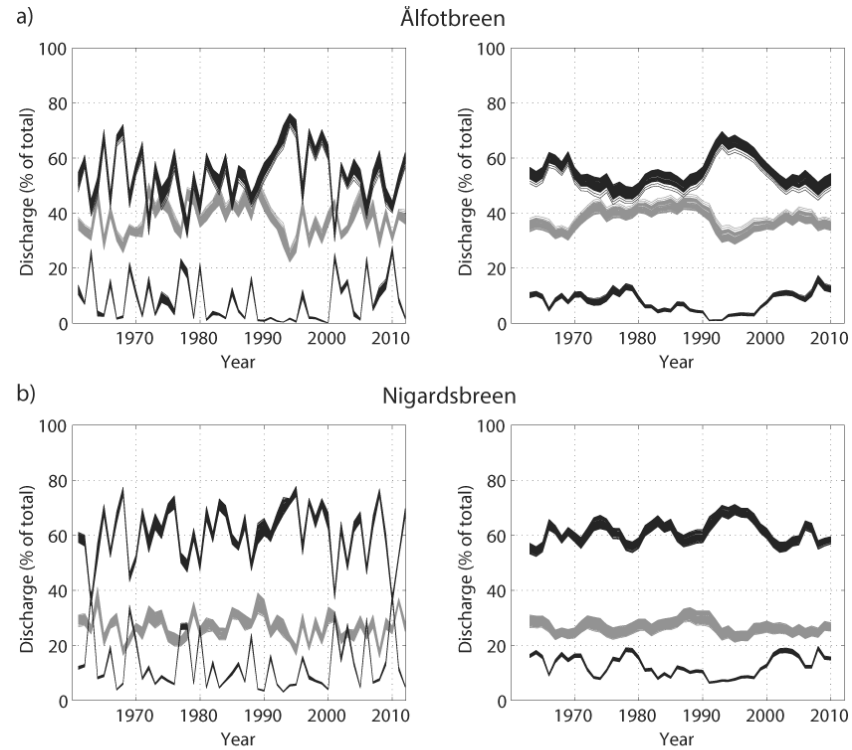

Nigardsbreen

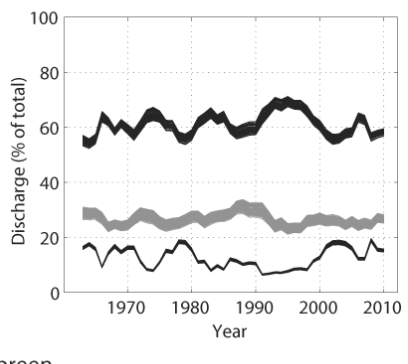

c)

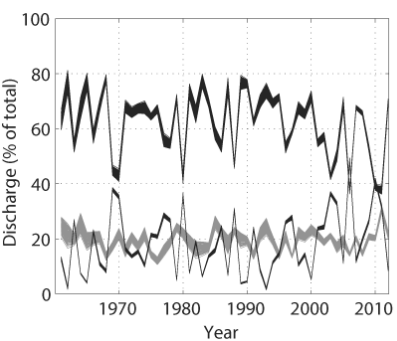

Storbreen

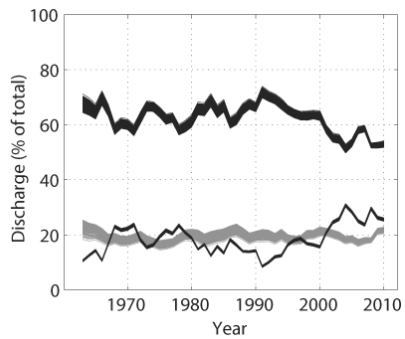

Fig. 8. Relative proportions of the contributing sources to the annual discharge (left column), and the respective $5 \mathrm{yr}$ moving average (right column). Snowmelt is represented by the upper black lines, glacier melt by the lower black lines and rain by the grey lines. catchments the majority of discharge occurred in the three months of June, July and August (Figs. 9, 10), accounting for about $60 \%$ of the annual discharge for Ålfotbreen, $75 \%$ for Nigardsbreen and $85 \%$ for Storbreen. At all sites, the maximum of both, snowmelt and total discharge, is in July. However, from the 1990s to the 2000s snowmelt increased in May and June and decreased from July to September. While in the 2000s in June, about $80 \%$ of the discharge derived from snowmelt for all three catchments, this proportion decreased within two months in August to less than half of the discharge for Nigardsbreen and to a third for Ålfotbreen and Storbreen. The maximum of glacier melt occurred at all catchments in August. In the 2000s glacier melt accounted for about a third of the discharge in August at Alfotbreen and Nigardsbreen, and more than $50 \%$ at Storbreen.

The most obvious difference between the two decades 1991-2000 and 2000-2010 is the increase in glacier melt at all sites. Due to increased snowmelt in May and June and increased glacier melt in August and September, the total discharge increased in almost all months from May through to October.

Correlation between meteorological input and annual discharge revealed a very high correlation of annual discharge with annual precipitation at Ålfotbreen (Table 4). The correlation was almost as high with winter precipitation (OctoberApril). However, at Nigardsbreen and Storbreen, annual discharge was highest correlated with summer temperatures (May-September). While at Storbreen summer temperatures were also most strongly correlated with annual glacier melt (Table 5), both Nigardsbreen and Alfotbreen show that glacier melt was strongly negatively correlated with the annual precipitation sum. 

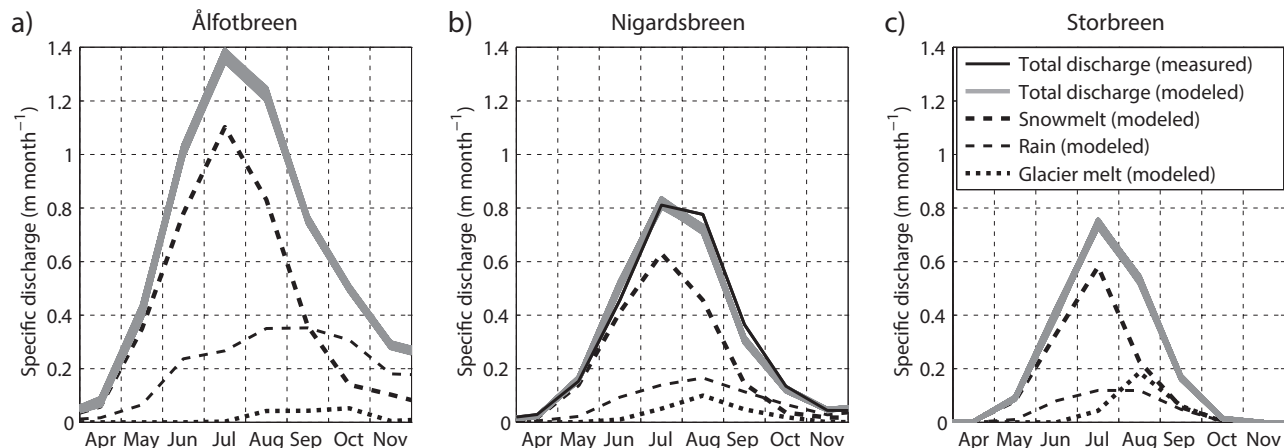

Fig. 9. Modelled monthly discharge rates and their contributing sources for Ålfotbreen, Nigardsbreen and Storbreen averaged for the period 1991-2000. Data for the contributing sources represent the mean of the 100 best model runs.
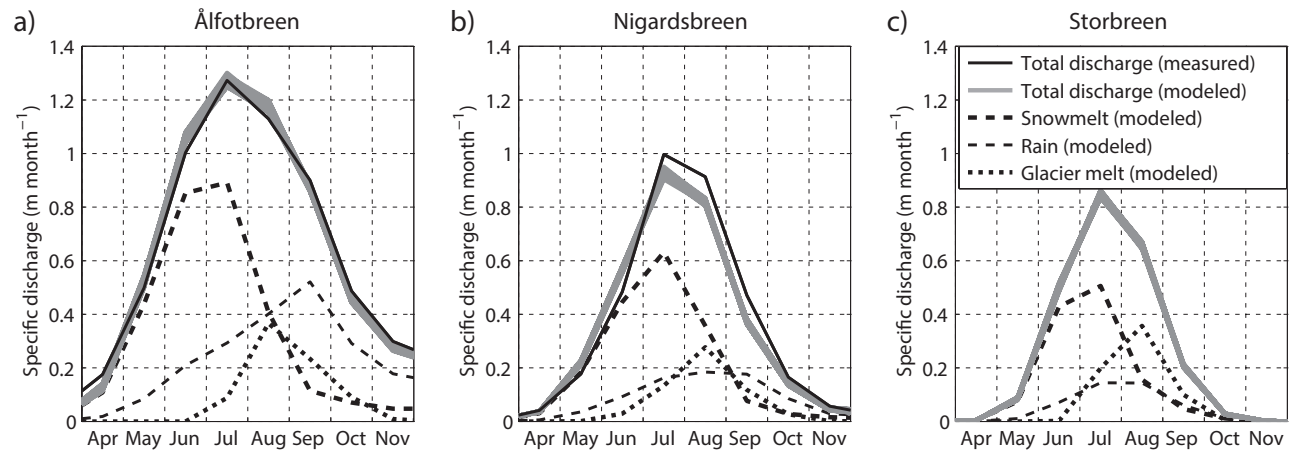

Fig. 10. Modelled monthly discharge rates and their contributing sources for Ålfotbreen, Nigardsbreen and Storbreen averaged for the period 2001-2010. Data for the contributing sources represent the mean of the 100 best model runs.

Table 4. Correlation coefficient of annual discharge sums (OctoberSeptember) for the model period 2001-2010.

\begin{tabular}{lccc}
\hline & Alfotbreen & Nigardsbreen & Storbreen \\
\hline $\begin{array}{l}\text { Mean annual air temperature } \\
\text { (October-September) }\end{array}$ & 0.66 & 0.57 & 0.48 \\
$\begin{array}{l}\text { Mean summer temperature } \\
\text { (May-September) }\end{array}$ & 0.21 & 0.78 & 0.93 \\
$\begin{array}{l}\text { Annual precipitation sum } \\
\text { (October-September) }\end{array}$ & 0.87 & 0.17 & 0.05 \\
$\begin{array}{l}\text { Winter precipitation sum } \\
\text { (October-April) }\end{array}$ & 0.85 & 0.20 & 0.01 \\
\hline
\end{tabular}

Table 5. Correlation coefficient of annual glacier melt for the model period 2001-2010.

\begin{tabular}{lccc}
\hline & Ålfotbreen & Nigardsbreen & Storbreen \\
\hline $\begin{array}{l}\text { Mean annual air temperature } \\
\text { (October-September) }\end{array}$ & -0.15 & -0.51 & -0.06 \\
$\begin{array}{l}\text { Mean summer temperature } \\
\text { (May-September) }\end{array}$ & 0.32 & 0.30 & 0.75 \\
$\begin{array}{l}\text { Annual precipitation sum } \\
\text { (October-September) }\end{array}$ & -0.76 & -0.88 & -0.66 \\
$\begin{array}{l}\text { Winter precipitation sum } \\
\text { (October-April) }\end{array}$ & -0.67 & -0.85 & -0.66 \\
\hline
\end{tabular}

\section{Discussion}

The modelled increase in annual discharge at Ålfotbreen from the 1960s to 1980s corresponds to an increase in precipitation during this period. Although mean summer temperatures at this site remained unchanged until the 1990s, the relative contribution from glacier melt decreased. The increasing precipitation led to both, increased discharge and to a mass gain, since more of the winter snow did not melt away. Measurements show an average annual mass balance on Ålfotbreen of $+0.5 \mathrm{~m} \mathrm{a}^{-1}$ from 1965 to 1995 (Kjøllmoen et al., 2011). The largest variations in annual discharge at Ålfotbreen can be attributed to larger variations in precipitation and to the higher mass-balance sensitivity of maritime glaciers to precipitation changes, which was also found in previous studies (e.g. Xu et al., 2012). On Nigardsbreen and Storbreen the increase in precipitation from the 1960s to 1990 s was much smaller. In addition, the coinciding decrease in glacier melt led to almost unchanged mean discharge for these two catchments until the 1990s. In general, an increase in winter precipitation leads to increased snowfall, positive mass balances and reduced glacier melt during summer. At Nigardsbreen, increased winter precipitation was the reason for positive mass balances and the advance of the 
glacier tongue in the 1990s (Winkler et al., 2009). While the annual precipitation slightly decreased at Nigardsbreen and Storbreen in the 2000s, the increase in discharge in the same period can be attributed to the increased summer temperature of $1-1.5 \mathrm{~K}$. At all three sites, increasing temperatures after the mid 1990s and decreasing precipitation resulted in reduced snow depths and increased glacier melt.

Among the three study sites, annual discharge at Alfotbreen is most sensitive to changes in precipitation (Table 4). The contribution of snow from areas outside the glacier at Ålfotbreen together with the large contribution from rain are the dominant factors in annual discharge at this site. At Nigardsbreen, where the glacier-free area is $<30 \%$ and where precipitation is much smaller than at Alfotbreen, the annual discharge, like for Storbreen, is most sensitive to summer temperature.

The correlation of glacier melt with temperature changes is largest on Storbreen (Table 5). Compared to Ålfotbreen, the annual precipitation at Storbreen is only about a third. The snow depth at the end of winter is accordingly lower, which leads to an earlier start of bare ice on Storbreen. Variations in glacier melt are therefore more strongly correlated with variations in summer temperature at Storbreen, whereas at both Nigardsbreen and Ålfotbreen glacier melt is most closely correlated with precipitation. A slightly higher correlation of glacier melt with annual rather than winter precipitation at these two sites is due to the fact that summer precipitation also indirectly affects glacier melt. Rainy days in summer coincide with more than average cloud cover and lower temperatures. In addition, snowfall events in summer even prevent glacier melt for several days (Oerlemans, 2004).

Previous studies (e.g. Chen and Ohmura, 1990) found that with increasing glacierization of a catchment, the occurrence of the maximum monthly runoff is delayed, and with decreasing glacier coverage the correlation of annual discharge with annual precipitation increases. We can partly sustain this finding for the lowest glaciated catchment of Ålfotbreen showing the highest correlation of annual discharge with annual precipitation sum, whereas for Nigardsbreen and Storbreen the annual discharge is most correlated with mean summer temperature. However, considering the relatively small range of glacier cover difference in our study sites (51-72\%), the correlation of annual discharge with annual precipitation reflects predominantly the climate continentality of the catchments rather than glacier coverage.

Long-term forecast for western Norway indicates a rise in the summer temperature of about $2{ }^{\circ} \mathrm{C}$ by the end of the 21 st century (Nesje et al., 2008). For Storbreen, such an increase will double the period of potential glacier melt (Andreassen and Oerlemans, 2009). High glacier melt rates lead to a decrease in the glacier area and thus discharge would decrease especially in August when at Storbreen for 20012010 glacier melt accounted on average for more than $50 \%$ of the discharge (Fig. 10c), which is in accordance with similar studies for the Alps (e.g. Finger et al., 2012).

\section{Conclusions}

In this study annual discharge series for the past five decades were modelled for three glacierised catchments in Norway. The model was calibrated through comparisons of modelled and observed seasonal mass balances and daily discharge sums. The time series of modelled annual discharge were split up into their contributing water sources snowmelt, glacier melt and rain. Changes in these contributing sources during the modelling period were much larger than variations in annual discharge sums.

Due to their location in different climate settings, the three studied catchments are representative of glaciers in Norway. Although for discharge, both year-to-year variability and variability throughout the year are largest at Ålfotbreen, the catchments closest to the western coast, glaciers with greater distance from the coast like Storbreen would experience larger changes in the discharge regime. Differences between the catchments in the seasonal discharge regimes and in year-to-year variability could be attributed to the large precipitation gradient and therefore to increasing climate continentality from west to east rather than differences in catchment size or degree of glacier coverage.

Discharge at the most maritime glacier Ålfotbreen is most strongly correlated with changes in precipitation, whereas discharge at the most continental catchment of Storbreen is most strongly correlated with changes in summer temperatures. Especially for Storbreen, glacier melt is a large contributor to discharge in late summer, which may lead to reduced discharge at this time of the year when its glacier area decreases.

In order to extrapolate the results into the future, a reduction in the glacierised area has to be accounted for when enhanced glacier melt has caused glacier volume to decrease significantly.

Acknowledgements. This publication is contribution number 29 of the Nordic Center of Excellence SVALI, "Stability and Variations of Arctic Land Ice", funded by the Nordic Top-level Research Initiative (TRI).

The authors want to thank Statkraft and the glacier group of the Norwegian Water Resources and Energy Directorate (NVE) for supporting fieldwork, as well as collecting and providing data for this study. We also thank the Institute for Marine and Atmospheric Research, Utrecht (IMAU) for operating and providing data from the automatic weather station on Storbreen.

The authors want to thank the scientific editor Jan Seibert and especially two anonymous referees who contributed with constructive comments to significantly improving the manuscript.

Edited by: J. Seibert 


\section{References}

Andreassen, L. M. and Oerlemans, J.: Modelling long-term summer and winter balances and the climate sensitivity of Storbreen, Norway, Geogr. Ann. A, 91 A, 233-251, 2009

Andreassen, L. M., Elvehøy, H., Kjøllmoen, B., Engeset, R. V., and Haakensen, N.: Glacier mass-balance and length variations in Norway, Ann. Glaciol., 42, 317-325, 2005.

Andreassen, L. M., van den Broeke, M. R., Giesen, R. G., and Oerlemans, J.: A 5 year record of surface energy and mass balance from the ablation zone of Storbreen, Norway, J. Glaciol., 54, 245-258, 2008.

Andreassen, L. M., Winsvold, S. H., Paul, F., and Hausberg, J. E.: Inventory of norwegian glaciers, - Report no. 38, 1-236, Norwegian Water Resources and Energy Directorate (NVE), Oslo, Norway, 2012.

Braun, L. N., Aellen, M., Funk, M., Hock, R., Rohrer, M. B., Steinegger, U., Kappenberger, G., and Müller-Lemans, H.: Measurement and simulation of high alpine water balance components in the Linth-Limmern head watershed (north-eastern Switzerland), Z. Gletscherk. Glazialgeol., 30, 161-185, 1994.

Chen, J. and Ohmura, A.: On the influence of Alpine glaciers on runoff, in: Hydrology in Mountainous Regions I - Hydrological Measurements; the Water Cycle (Proceedings of two Lausanne Symposia, August 1990: IAHS Publ. no. 193) 117-126, 1990.

Dahlke, H. E., Lyon, S. W., Stedinger, J. R., Rosqvist, G., and Jansson, P.: Contrasting trends in floods for two sub-arctic catchments in northern Sweden - does glacier presence matter?, Hydrol. Earth Syst. Sci., 16, 2123-2141, doi:10.5194/hess-16-21232012, 2012.

Dyrrdal, A. V.: An evaluation of Norwegian snow maps: simulation results versus observations, Hydrol. Res., 41, 27-37, doi:10.2166/nh.2010.019, 2010.

Elsberg, D. H., Harrison, W. D., Echelmeyer, K. A., and Krimmel, R. M.: Quantifying the effects of climate and surface change on glacier mass balance, J. Glaciol., 47, 649-658, doi:10.3189/172756501781831783, 2001.

Engelhardt, M., Schuler, T. V., and Andreassen, L. M.: Evaluation of gridded precipitation for Norway using glacier mass-balance measurements, Geogr. Ann. A, 94, 501-509, doi:10.1111/j.14680459.2012.00473.x, 2012.

Engelhardt, M., Schuler, T. V., Andreassen, L. M.: Glacier mass balance of Norway from 1961-2010 calculated by a temperature-index model, Ann. Glaciol., 54, 32-40, doi:10.3189/2013AoG63A245, 2013.

Farinotti, D., Usselmann, S., Huss, M., Bauder, A., and Funk, F.: Runoff evolution in the Swiss Alps: projections for selected highalpine catchments based on ENSEMBLES scenarios, Hydrol. Process., 26, 1909-1924, doi:10.1002/hyp.8276, 2012.

Finger, D., Pellicciotti, F., Konz, M., Rimkus, S., and Burlando, P.: The value of glacier mass balance, satellite snow cover images, and hourly discharge for improving the performance of a physically based distributed hydrological model, Water Resour. Res., 47, W07519, doi:10.1029/2010wr009824, 2011.

Finger, D., Heinrich, G., Gobiet, A., and Bauder, A.: Projections of future water resources and their uncertainty in a glacierized catchment in the swiss alps and the subsequent effects on hydropower production during the 21 st century, Water Resour. Res., 48, W02521, doi:10.1029/2011wr010733, 2012.
Gebremedhin, A. and De Oliveira Granheim, J.: Is there a space for additional renewable energy in the Norwegian power system? Potential for reduced global emission?, Renew. Sustain. Energ. Rev., 16, 1611-1615, doi:10.1016/j.rser.2011.11.032, 2012.

Hock, R.: A distributed temperature-index ice- and snowmelt model including potential direct solar radiation, J. Galciol., 45, 101$111,1999$.

Hock, R.: Temperature index modelling in mountain areas, J. Hydrol., 282, 104-115, 2003.

Hock, R.: Glacier melt. A review on processes and their modelling, Prog. Phys. Geogr., 29, 362-291, 2005.

Hock, R. and Noetzli, C.: Aerial melt and discharge modelling of Storglaciä ren, Sweden, Ann. Galciol., 24, 211-216, 1997.

Hock, R., Jansson, P., and Braun, L.: Modelling the response of mountain glacier discharge to climate warming, in: Global Change and Mountain Regions - A State of Knowlegde Overview, edited by: Huber, U. M., Bugmann, H. K. M., and Reasoner, M. A., 243-252, Springer, Dordrecht, The Netherlands, 2005.

Hock, R., Rees, G., Williams, M. W., and Ramirez, E.: Preface: Contribution from glaciers and snow cover to runoff from mountains in different climates, Hydrol. Process., 20, 2089-2090, 2006.

Huss, M.: Present and future contribution of glacier storage change to runoff from macroscale drainage basins in Europe, Water Resour. Res., 47, W07511, doi:10.1029/2010WR010299, 2011.

Huss, M., Farinotti, D., Bauder, A., and Funk, M.: Modelling runoff from highly glacierized alpine drainage basins in a changing climate, Hydrol. Process., 22, 3888-3902, doi:10.1002/hyp.7055, 2008.

Huss, M., Funk, M., and Ohmura, A.: Strong Alpine glacier melt in the 1940 s due to enhanced solar radiation, Geophys. Res. Lett., 36, L23501, doi:10.1029/2009GL040789, 2009.

Huss, M., Jouvet, G., Farinotti, D., and Bauder, A.: Future highmountain hydrology: a new parameterization of glacier retreat, Hydrol. Earth Syst. Sci., 14, 815-829, doi:10.5194/hess-14-8152010, 2010.

Immerzeel, W. W., van Beck, L. P. H., Konz, M., Shrestha, A. B., and Bierkens, M. F. P.: Hydrological response to climate change in a glacierized catchment in the Himalayas, Clim. Change, 110, 721-736, doi:10.1007/s10584-011-0143-4, 2012.

Jost, G., Moore, R. D., Menounos, B., and Wheate, R.: Quantifying the contribution of glacier runoff to streamflow in the upper Columbia River Basin, Canada, Hydrol. Earth Syst. Sci., 16, 849-860, doi:10.5194/hess-16-849-2012, 2012.

Kjøllmoen, B., Andreassen, L., Elvehøy, H., and Giesen, M. J. R. H.: Glaciological investigations in Norway in 2010, Report no. 3, Norwegian Water Resources and Energy Directorate (NVE), Oslo, Norway, 2011.

Klok, E. J., Jasper, K., Roelofsma, K. P., Gurtz, J., and Badoux, A.: Distributed hydrological modelling of a heavily glaciated Alpine river basin, Hydrol. Sci. J., 46, 553-570, doi:10.1080/02626660109492850, 2001.

Konz, M. and Seibert, J.: On the value of glacier mass balances for hydrological model calibration, J. Hydrol., 385, 238-246, doi:10.1016/j.jhydrol.2010.02.025, 2010. 
Li, L., Engelhardt, M., Xu, C.-Y., Jain, S. K., and Singh, V. P.: Comparison of satellite-based and re-analysed precipitation as input to glacio-hydrological modelling for Beas River basin, northern India, Cold and Mountain Region Hydrological Systems Under Climate Change: Towards Improved Projections, Proceedings of H02, IAHS-IAPSO-IASPEI Assembly, Gothenburg, Sweden, July 2013 (IAHS Publ. 360, 2013), 45-52, 2013.

Martinec, J.: Expected snow loads on structures from incomplete hydrological data, J. Glaciol., 19, 185-195, 1977.

Mayr, E., Hagg, W., Mayer, C., and Braun, L.: Calibrating a spatially distributed conceptual hydrological model using runoff, annual mass balance and winter mass balance, J. Hydrol., 478, 4049, doi:10.1016/j.jhydrol.2012.11.035, 2013.

Mohr, M.: New routines for Gridding of Temperature and Precipitation Observations for "senorge.no", Norwegian Meteorological Institute (met.no) note no. 08/2008, 40 pp., available at: http://met.no/Forskning/Publikasjoner/Publikasjoner2008/ filestore/NewRoutinesforGriddingofTemperature.pdf, 2008.

Mohr, M.: Comparison of versions 1.1 and 1.0 of gridded temperature and precipitation data for Norway, Norwegian Meteorological Institute (met.no) note no. 19/2009, 44 pp., available at: http://met.no/Forskning/Publikasjoner/ Publikasjoner2009/filestore/note19-09.pdf, 2009.

Nesje, A., Bakke, J., Dahl, S. O., Lie, Ø., and Matthews, J. A.: Norwegian mountain glaciers in the past, present and future, Global Planet. Change, 60, 10-27, 2008.

Oerlemans, J.: Effect of summer snowfall on glaciermass balance, Ann. Glaciol., 38, 97-100, 2004.

Ohmura, A.: Physical Basis for the Temperature-Based Melt-Index Method, Am. Meteorol. Soc., 46, 753-761, 2001.

Østrem, G. and Brugman, M. M.: Glacier mass-balance measurements: a manual for field and office work - Scientific report no. 4, National Hydrology Research Institute, Saskatoon, Canada and Norwegian Water Resources and Energy Directorate (NVE), Oslo, Norway, 1991.
Sælthun, N. R.: The "Nordic" HBV Model. Description and documentation of the model version developed for the project Climate Change and Energy Production. - Report no. 218, 7 pp., Norwegian Water Resources and Energy Directorate (NVE), Oslo, Norway, 1996.

Saloranta, T. M.: Simulating snow maps for Norway: description and statistical evaluation of the seNorge snow model, The Cryosphere, 6, 1323-1337, doi:10.5194/tc-6-1323-2012, 2012.

Schaner, N., Voisin, N., Nijssen, B., and Lettenmeier, D. P.: The contribution of glacier melt to streamflow, Environ. Res. Lett., 7, 1-8, doi:10.1088/1748-9326/7/3/034029, 2012.

Sicart, J. E., Hock, R., and Six, D.: Glacier melt, air temperature, and energy balance in different climates: The Bolivian Tropics, the French Alps, and northern Sweden, J. Geophys. Res., 113, D24113, doi:10.1029/2008JD010406, 2008.

Stahl, K., Moore, R. D., Shea, J. M., Hutchinson, D., and Cannon, A. J.: Coupled modelling of glacier and streamflow response to future climate scenarios, Water Resour. Res., 44, W02422, doi:10.1029/2007WR005956, 2008.

Verbunt, M., Gurtz, J., Jasper, K., Lang, H., Warmerdam, P., and Zappa, M.: The hydrological role of snow and glaciers in alpine river basins and their distributed modeling, J. Hydrol., 282, 3655, doi:10.1016/S0022-1694(03)00251-8, 2003.

Winkler, S., Elvehøy, H., and Nesje, A.: Glacier fluctuations of Jostedalsbreen, western Norway, during the past 20 years: the sensitive response of maritime mountain glaciers, The Holocene, 19, 395-414, doi:10.1177/0959683608101390, 2009.

Xu, M., Yan, M., Kang, J., and Ren, J.: Comparative studies of glacier mass balance and their climatic implications in Svalbard, Northern Scandinavia, and Southern Norway, Environ. Earth Sci., 67, 1407-1414, doi:10.1007/s12665-012-1585-3, 2012. 